\title{
ROOTSTOCK-SCION INTERACTION: 1. EFFECT ON THE YIELD COMPONENTS OF CABERNET SAUVIGNON GRAPEVINE ${ }^{1}$
}

\author{
ALBERTO MIELE² \& LUIZ ANTENOR RIZZON ${ }^{2}$
}

ABSTRACT - The interaction between rootstock, scion and environment can induce different responses to the grapevine physiology. Thus, the aim of this study was to determine the rootstock effect on the yield components of Cabernet Sauvignon (CS) grapevine grown in the Serra Gaúcha viticultural region. The experimental design was completely randomized blocks, with 15 treatments, three replicates and ten vines per plot. The results show that all variables evaluated were significantly affected by the year and the rootstock. The CS/Solferino was among other combinations influenced by the year and had higher significant yield/ vine. Indeed, it was higher than that CS/Rupestris du Lot, CS/101-14 Mgt., CS/3309 C, CS/5BB K, CS/161$49 \mathrm{C}, \mathrm{CS} / 1103$ P. and CS/Isabel. The number of clusters/bud, per burst bud and per vine and the weight of clusters were affected by the rootstock as well. Pruning weight/vine, yield/pruning weight, leaf area/vine, leaf area index and leaf area/fresh fruit weight are variables related to the physiology of grapevine which were also affected by the rootstock. In general, rootstocks had adapted well to the environment where the experiment was carried out, giving vigor and high yield to Cabernet Sauvignon grapevine, which means that they may be used by grape growers in this region. However, the choice of the right rootstock depends on various aspects, such as those related to the soil characteristics, climate conditions, grape varieties, and even clones, and production purposes.

Index terms: grape, Vitis vinifera, grafting, production.

\section{INTERAÇÃO ENTRE COPA E PORTA-ENXERTO: 1. EFEITO NOS COMPONENTES DE PRODUÇÃO DA VIDEIRA CABERNET SAUVIGNON}

RESUMO - A interação entre porta-enxerto, copa e meio ambiente pode induzir diferentes respostas à fisiologia da videira. Assim, o objetivo deste estudo foi determinar o efeito do porta-enxerto nos componentes de produção da videira Cabernet Sauvignon (CS) cultivada na região vitivinícola da Serra Gaúcha. O delineamento experimental foi inteiramente casualizado, com 15 tratamentos, três repetições e dez plantas por parcela. Os resultados mostram que todas as variáveis avaliadas foram significativamente afetadas pelo ano e pelo porta-enxerto. A combinação CS/Solferino está entre as combinações que foram afetadas significativamente e apresentaram maior produtividade/planta. De fato, ela foi superior a CS/Rupestris du Lot, CS/101-14 Mgt., CS/3309 C, CS/5BB K, CS/161-49 C, CS/1103P e CS/Isabel. O número de cachos por gema, por gema brotada e por planta e o peso por cacho também foram afetados significativamente pelo ano e pelo porta-enxerto. O peso da poda/planta, a produção/peso da poda, a área foliar/planta, o índice de área foliar e a área foliar/peso de frutos frescos são variáveis relacionadas à fisiologia da videira que também foram afetadas pelo porta-enxerto. Em geral, os porta-enxertos adaptaram-se bem ao ambiente em que foi conduzido o trabalho, transmitindo vigor e alta produtividade à videira Cabernet Sauvignon, o que significa que eles podem ser usados por viticultores dessa região. No entanto, a escolha do porta-enxerto depende de vários aspectos, tais como os relacionados às características do solo, condições climáticas, cultivares de uva, e até mesmo clones, e propósitos da produção.

Termos para indexação: uva, Vitis vinifera, enxertia, produção.

1(Paper 165-15). Received June 23, 2016. Accepted October 07, 2016

2Embrapa Uva e Vinho, CEP 95701-008 Bento Gonçalves-RS, Brazil. E-mails: alberto.miele@embrapa.br; luiz.rizzon@terra.com.br 


\section{INTRODUCTION}

The selection of the right rootstock depends on some characteristics of the interaction between rootstock, scion and environment. Scion, the physicochemical properties of soil and the presence of organisms, such as insects, fungi and nematodes stand out among the main factors. Furthermore, production objective should also be considered. These characteristics can induce different responses to the grapevine-yield components and to the grape and wine composition and its sensory attributes. In fact, each factor per se, and mainly the interaction between them, can unevenly induce mineral assimilation by roots, sap translocation in the xylem system and accumulation in the grapevine tissue, leading to the biosynthesis of a wide range of compounds, different biochemical reactions and consequently grapevine physiology.

Grapevines (Vitis vinifera L.) are grafted on rootstocks resistant to phylloxera (Daktulosphaira vitifoliae) in most viticultural regions of the world. This insect appeared in European ownrooted vineyards in the $1850 \mathrm{~s}$ where it devastated considerable areas, and then it spread to other regions worldwide. Later, French researchers found that the problem could be resolved by grafting European grapevines on American species (POUGET, 1990).

Since then, most vineyards are established with grafted grapevines. Earlier, single American species had been used for this purpose. Today, most rootstocks are derived from crossing two or more Vitis species. Indeed, there is considerable diversity of rootstocks, each presenting characteristics searched by grape growers for a particular condition. The most important are related to soil parasites, climate adversities, adaptability to soil mineral excess or deficiency and grapevine vigor.

There are works covering different aspects of the influence of rootstocks on grapevine, such as those related to physiology (VIRGONA et al., 2003; COOKSON et al., 2012), biochemistry (SOMKUWAR et al., 2014; SOUZA et al., 2015), mineral nutrition (MIELE et al., 2009; KODUR et al., 2011), yield (TERRA et al., 2003; KELLER et al., 2012), water deficiency or excess (DE HERALDE et al., 2006; SERRA et al., 2014), salinity (WALKER et al., 2007), fungal diseases (BROWN et al., 2013; WALLIS et al., 2013), viruses (ROSA et al., 2011) and nematodes (FERRIS et al., 2012).

Serra Gaúcha vineyards are established on various types of soil, as Neossolos Litólicos, Cambissolos and Nitossolos (Lithic Neosols, Inceptisols and Ultisols, respectively, according to Soil Taxonomy), which represent about $89 \%$ of the total area, each with specific physicochemical properties (C.A. Flores, personal communication). In general, in this region, grapevines grow and develop well without setbacks related to soil type, which means they are well adapted to these conditions. In addition, vineyards made up with own-rooted Vitis labrusca varieties, or hybrids, have been cultivated for several years, fifty or more, without showing major problems. However, one of the most important constraints of Serra Gaúcha soils is the presence of fungus Fusarium oxysporum f. sp. herbemontis, which, as far as is known, is not considered a great problem elsewhere. Therefore, researches have been carried out in order to verify the susceptibility of rootstocks to this fungus (GRIGOLETTI JÚNIOR, 1993; SÔNEGO, 1998). More recently, researchers and growers have been concerned about other species of fungi present in viticultural soils. Another problem could be related to the ground pearl (Eurhizococcus brasiliensis), insect that feeds on the grapevine root sap, which is present in some soils. To control this pest, specific insecticides may be used. However, some vegetative materials of the Vitis rotundifolia species are suggested as rootstock due to their relative resistance to E. brasiliensis (BOTTON; DALLA COLLETA, 2010). Concerning nematodes, there are very few experiments being conducted in Brazil, most of them studying the presence of different species. However, there seems to be no major problems with Serra Gaúcha vineyards nowadays.

In this sense, this research aimed to determine the effect of 15 rootstocks on the yield components of Cabernet Sauvignon grapevine grown in a Cambissolo soil of Serra Gaúcha.

\section{MATERIAL AND METHODS}

The experiment was carried out for two consecutive years - 1998/1999 and 1999/2000 - in the Serra Gaúcha viticultural region, Brazil. The soil, a Cambissolo (Inceptisol, according to Soil Taxonomy), was analyzed and had the following

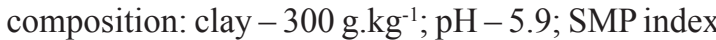
- 6.2; organic matter -27 g. $\mathrm{kg}^{-1} ; \mathrm{P}-11 \mathrm{mg} \cdot \mathrm{kg}^{-1}$; $\mathrm{K}-0.44 \mathrm{cmol}_{\mathrm{c}} \mathrm{kg}^{-1} ; \mathrm{Ca}-940 \mathrm{cmol} \mathrm{dm}^{-3} ; \mathrm{Mg}-270$ $\mathrm{cmol} \mathrm{dm}^{-3}$. According to this analysis, $75 \mathrm{~kg} \cdot \mathrm{ha}^{-1}$ of $\mathrm{P}_{2} \mathrm{O}_{5}$ were incorporated to the low-north facing slope soil. The presence or absence of fungi, insects and nematodes was not evaluated in this study.

Subsequently, the vineyard was established by placing dormant cuttings in soil with previously opened holes measuring $30 \mathrm{~cm}$ in length $\mathrm{x} 30 \mathrm{~cm}$ in width $\mathrm{x} 40 \mathrm{~cm}$ in depth. The distance between 
east-west-oriented rows was $2.5 \mathrm{~m}$ and within rows $1.8 \mathrm{~m}$. Thus, there were 2,222 grapevines.ha ${ }^{-1}$. In the next two years, the shoots on the lower part of trunk canes were removed during summer and the main trunks were tied to a straight cane stake. In the winter of the second year, they were cut off and cleft grafted. During spring and summer, shoots were tied to stakes and in the third year after grafting, when they reached the pergola trellis wire, they were topped about $10 \mathrm{~cm}$ below the production wire, which promoted the development of two terminal laterals. These laterals were conducted to form the grapevine architecture, i.e., they were had-trained, cane-pruned (Guyot system). During pruning, the number of buds left in each grapevine varied according to plant vigor, i.e., in a vigorous vine, more buds were left, compared to a less vigorous vine. Considering both years, 1999 and 2000, there were 42.1 and 47.8 buds/vine, respectively, on average. Diseases and pests were controlled with specific fungicides and insecticides during the entire grapevine vegetative cycles, fertilizers were not applied at any time and inter-rows were mechanically kept clean from weeds.

Treatments consisted of 15 rootstocks, i.e., Rupestris du Lot (Vitis rupestris); 101-14 Mgt. and 3309 Couderc (both Vitis riparia $\mathrm{x}$ Vitis rupestris); 420A Mgt., 5BB Kober, 161-49 Couderc and SO4 (all Vitis berlandieri x Vitis riparia); 1103 Paulsen, 99 Richter and 110 Richter (all Vitis berlandieri $\mathrm{x}$ Vitis rupestris); Gravesac (Vitis berlandieri $\mathrm{x}$ Vitis rupestris) x (Vitis riparia $\mathrm{x}$ Vitis rupestris); Fercal (Vitis berlandieri $\mathrm{x}$ Vitis vinifera) $\mathrm{x}$ (Vitis vinifera $\mathrm{x}$ Vitis berlandieri); Dogridge (Vitis champini); Isabel (Vitis labrusca); and Solferino (local name of an unknown rootstock). In fact, Isabel is not a rootstock, but the most cultivated grapevine in Serra Gaúcha, whose production is intended to supply wineries to produce common wine and grape juice. Twelve rootstocks came from grapevines free from viruses and three rootstocks (Isabel, Solferino and Dogridge) came from grapevines apparently free from viruses. Fercal and Gravesac were kindly provided by InraCentre Bordeaux-Aquitaine, for research purpose only, which were eliminated after the completion of the experiment, and the others came from Embrapa Uva e Vinho. Cabernet Sauvignon (CS) scions were also considered free from viruses and were collected from a vineyard established at Embrapa Uva e Vinho using vegetative material from Inra-Centre Bordeaux-Aquitaine. These 15 rootstocks together feature some genetic characteristics required by growers; however, they certainly did not cover all types of problems that could occur in the field.

The experimental design was completely randomized blocks, with 15 treatments (rootstocks), three replicates and ten grapevines per plot. In this way, the area of each block was $675 \mathrm{~m}^{2}$ and the entire experimental area was $2,025 \mathrm{~m}^{2}$. In addition, there were external and internal grapevine borders.

Variables were evaluated according to the following procedures: 1) budbreak (\%), by the number of burst buds multiplied by 100 and divided by the number of total buds. This was done by counting the number of burst buds of canes and spurs about 30 days after sprouting; 2) number of clusters per bud, by dividing the number of clusters by the number of buds; 3 ) number of clusters per bud burst, by dividing the number of clusters by the number of burst buds; 4) number of clusters per vine, by counting the total vine clusters; 5) yield per bud (g), by dividing yield by the number of buds; 6) yield per burst bud (g), by dividing yield by the number of burst buds; 7) cluster weight (g), by dividing yield by the number of clusters; 8 ) yield per vine $(\mathrm{kg})$, by dividing yield by the number of vines; 9) pruning weight per vine $(\mathrm{kg})$, by weighing the canes of each vine pruned during the rest period; 10) yield/pruning weight ratio $(\mathrm{kg} / \mathrm{kg})$, by dividing yield by pruning weight; 11) leaf area per vine $\left(\mathrm{m}^{2}\right)$, by multiplying the mean surface of leaves by the number of leaves per vine (the leaf area of Cabernet Sauvignon grapevine was estimated according to the sum of the two $\mathrm{N} 2$ lateral veins $\left(\mathrm{LA}=\sum \mathrm{N}_{2}\right.$, corresponding to the equation $\mathrm{y}=\mathrm{a}+\mathrm{bX}+\mathrm{cX}{ }^{2}$ ) (MIELE et al., 1989); 12) leaf area index (LAI), by dividing the leaf area $\left(\mathrm{m}^{2}\right)$ per vine by the soil surface $\left(\mathrm{m}^{2}\right)$ occupied by each vine; 13) leaf area per vine/fresh fruit weight ratio, by dividing the leaf area $\left(\mathrm{cm}^{2}\right)$ per yield $(\mathrm{g})$ of each vine.

Data related to the yield components of Cabernet Sauvignon grapevine grafted on 15 rootstocks in a Cambissolo soil of Serra Gaúcha were submitted to Anova and Tukey's multiple range test at $5 \%$ probability. In addition, correlations among variables were performed.

\section{RESULTS AND DISCUSSION}

Results of the effect of 15 rootstocks on the Cabernet Sauvignon grapevine-yield components are shown in Tables 1 and 2. The data show that there was a significant effect of rootstock and year on all variables evaluated, but an interaction between them was observed in only four variables.

The percentage of budbreak of the CS/110 R combination was $82.8 \%$, differing significantly from CS/3309 C (71.5\%) and CS/Dogridge (63.1\%) (Table1). The percentage of budbreak showed significant interaction between rootstock and year 
$(\mathrm{p}<0.005)$. In 1999, CS/Dogridge was among the combinations having the lowest percentages of budreak and it was significant different from the others, except for CS/3309 C, CS/Solferino and CS/ Isabel. In 2000, there was no significant difference among all combinations.

The number of clusters/bud was higher in CS/ $\mathrm{SO} 4, \mathrm{CS} / 1103 \mathrm{P}$ and CS/Gravesac than CS/Isabel $(p<0.005)$ and the number of clusters/burst bud was higher $(\mathrm{p}<0.05)$ in $\mathrm{CS} / 5 \mathrm{BB} \mathrm{K}$ and $\mathrm{CS} / \mathrm{SO} 4$ than $\mathrm{CS} /$ Isabel (Table 1). The number of clusters/vine was significantly higher $(\mathrm{p}<0.001)$ in $\mathrm{CS} /$ Solferino than CS/101-14 Mgt., CS/161-49 C and CS/Isabel.

The yield/bud was higher $(\mathrm{p}<0.001)$ in the combination $\mathrm{CS} / \mathrm{SO} 4$ and lower in CS/Rupestris du Lot, CS/101-14 Mgt. and CS/Isabel. The yield/burst bud of $\mathrm{CS} / \mathrm{SO} 4$ combination was significant different $(p<0.001)$ from CS/Rupestris du Lot and CS/Isabel (Table 1), however there was an interaction between rootstock and year. Indeed, in 1999, CS/Dogridge had higher yield/burst bud values than CS/101-14 Mgt., CS/161-49 C and CS/Isabel, but it showed no difference in 2000 from all other combinations.

$\mathrm{CS} /$ Solferino had higher yield/vine $(\mathrm{p}<0.001)$ than CS/Rupestris du Lot, CS/101-14 Mgt., CS/3309 C, CS/5BB K, CS/161-49 C, CS/1103 P and CS/ Isabel (Table 1). CS/Solferino yield was equivalent to 39.4 t.ha $^{-1}$, which means $52.8 \%$ higher than the average yield $\left(25.8\right.$ t.ha $\left.^{-1}\right)$ of other treatments that differed significantly from it. High productivities were also found in works carried out in similar conditions with Merlot (MIELE; MANDELLI, 2012) and Cabernet Sauvignon cultivars (MIELE; RIZZON, 2013). These high yields were achieved due to soil and climate characteristics and the trellising system used (pergola), because they offer conditions to grow vigorous grapevines. In addition, pergola system supports high number of buds and consequently high number of clusters per unit of soil surface. Yield/vine was positively correlated with the number of clusters/vine $(r=0.81)$, which explains why $\mathrm{CS} /$ Solferino had higher yield/vine than seven other scion/rootstock combinations. This result could also may be due to the number of clusters/bud, clusters/burst bud and cluster weight. Indeed, they showed significant correlations $-\mathrm{r}=0.61$ and $\mathrm{r}=0.31$, respectively - with yield/vine, which implies that these variables could also have had an effect on the high CS/Solferino yield.

Previous work has shown that the ${ }^{\circ}$ Brix of Cabernet Sauvignon grape was 0.8 lower when yield varied from 23.4 to 38.7 t.ha ${ }^{-1}$ (MIELE; RIZZON, 2013). However, ${ }^{\circ}$ Brix is only one variable related to grape quality. In addition, other substances such as polyphenols and volatile compounds usually have strong influence on wine composition and quality. Thus, it should be emphasized that, in general, high yield vineyards produce wine of lower or even poor quality. Therefore, technical recommendations have been given to growers to change from pergola to vertical system in order to leave less buds/vine and consequently to have lower yields. In addition, viticulturists are using other cultural practices to limit yield, such as appropriate canopy management. Therefore, under some conditions, it is advisable to graft scions on less vigorous rootstocks to insure lower yield.

Trials aiming to establish the effect of rootstocks on vineyard yield have been carried out all over the world (TERRA et al., 2003; ORLANDO et al., 2008; JONES et al., 2009; KELLER et al., 2012; SOUZA et al., 2015). In general, they have different characteristics, which are mainly related to rootstocks, scions, soil properties, climate conditions, grapevine management and crop objective. These differences led to results that are specific to each location, which means that they may not be considered of universal use. Indeed, one of these differences could be due to the scion effect and climate conditions that are more important than the rootstock effect on grapevine yield (KELLER et al., 2012). In the present work, the CS/1103 P was among the lowest productivities observed. This result is in accordance with previous works carried out with this cultivar (SOUZA et al., 2015) and with Merlot, Syrah and Chardonnay (KELLER et al., 2012). The CS/101-14 Mgt. yield was also among the lowest ones, which is in accordance with those found by Souza et al. (2015). In general, the variability in grapevine yield, as well as growth and fruit ripening and composition is determined by scion and spatial and temporal variability (KELLER et al., 2012).

The cluster weight was higher in CS/420A Mgt., CS/SO4, CS/Solferino and CS/Dogridge than CS/Rupestris du Lot, CS/3309 C and CS/1103 P $(\mathrm{p}<0.05)$ (Table 2).

Grapevine physiology may be evaluated by some variables, such as pruning weight/vine, yield/ pruning weight ratio, leaf area/vine, leaf area index and leaf area/fresh fruit weight ratio. Considering these variables, results have shown that CS/Dogridge and $\mathrm{CS} /$ Gravesac pruning weight/vine were higher $(p<0.001)$ than CS/101-14 Mgt., CS/3309 C, CS/420A Mgt., CS/161-49 C, CS/99 R, CS/110 R and CS/Isabel (Table 2). CS/Solferino was among the most vigorous combinations. Indeed, its pruning weight/vine value was, respectively, 2.51 and 2.35 times higher than CS/Isabel and CS/161-49 C. As 
Solferino is an unknown rootstock. it is not possible to compare its behavior with those of other works. Souza et al. (2015) showed that 101-14 Mgt. provided lower vigor to Cabernet Sauvignon compared to IAC 766 and Rupestris du Lot, results that are not in accordance with the present research at least regarding Rupestris du Lot.

Regarding the yield/pruning weight ratio, $\mathrm{CS} /$ Isabel had significant $(\mathrm{p}<0.001)$ higher values than CS/Rupestris du Lot, CS/101-14 Mgt., CS/3309 C, $\mathrm{CS} / 5 \mathrm{BB} \mathrm{K}, \mathrm{CS} / \mathrm{SO} 4, \mathrm{CS} /$ Gravesac, CS/Fercal and CS/Dogridge (Table 2), which was due to the data from both yield/vine and pruning weight/vine. The yield/pruning weight ratio gives a good idea of the relationship between reproductive and vegetative performance of a grapevine. Bravdo et al. (1985) showed that the balance between grapevine yield and pruning weight was obtained with parameters ranging from 4.6 to 12.0. The results found in the present work are, in general, in accordance with those mentioned above, but they agree with the lowest values because they ranged from 3.43 (CS/Dogridge) to 8.37 (CS/Isabel). The yield/pruning weight ratio parameters found in this work were due to the high grapevine vigor, which showed high pruning weight/ vine values (Table 2). This means that each vineyard should have a specific relationship between yield and pruning weight to have equilibrium between grapevine reproductive and vegetative growth and development to achieve a specific crop objective.

The leaf area/vine of CS/Rupestris du Lot was significant different $(<0.005)$ than $\mathrm{CS} / 110 \mathrm{R}$. However, there was significant interaction $(p<0.05)$ between rootstock and year. In 1999, the leaf area/ vine of CS/Dogridge was significant higher than CS/161-49 C, but in 2000 there was no significant effect. The leaf area index was higher $(\mathrm{p}<0.05)$ in CS/Rupestris du Lot, CS/SO4 and CS/Dogridge than CS/101-14 Mgt., CS/1611-49 C, CS/99 R, CS/110 $\mathrm{R}$ and $\mathrm{CS} /$ Gravesac, and a significant interaction between rootstock and year was observed. In 1999, CS/Dogridge had higher values than CS/161-49 C, but in 2000 there was no significant effect.

The leaf area/fresh fruit weight was higher in CS/Rupestris du Lot than CS/161-49 C, CS/ Solferino, CS/99 R, CS/110 R and CS/Gravesac (Table 2). Souza et al. (2015) showed that 101-14 Mgt. rootstock conferred lower vigor to Cabernet Sauvignon than did IAC 766 and Rupestris du Lot, results that are in accordance with the present research. The leaf area/fresh fruit weight ratio indicates the leaf area required to properly ripen the grapes of a vineyard. Differences among works ranging from 6.58 to $12.58 \mathrm{~cm}^{2}$ leaves. $\mathrm{g}^{-1}$ of fresh fruit weight were observed. It should be mentioned that there were significant correlations between leaf area/fresh fruit weight with leaf area/vine $(r=0.74)$, leaf area index $(\mathrm{r}=0.73)$, number of clusters/vine $(\mathrm{r}=$ $-0.57)$ and yield/vine $(r=-0.59)$.

Glucose and fructose, the two most important sugars of grapes, are synthesized in grapevine leaves by the photosynthesis process, and their concentrations in the fruit depend on a variety of factors. Total leaf area, especially of leaves exposed to sunlight, is one of the most important to accumulate these sugars in fruits. In this way, the leaf area/fresh fruit weight ratio is an important tool to evaluate fruit quality. According to Kliewer and Weaver (1971), each grapevine presents a specific capacity to synthesize, transport and accumulate adequate amounts of sugars. The ideal leaf area/fresh fruit weight ratio to mature grapes mainly depends on the characteristics of the vineyard, terroirs and crop objective. Results found in literature about this subject vary according to conditions in which trials were conducted. For example, there is a work showing that a minimum of $18 \mathrm{~cm}^{2}$ of leaves. $\mathrm{g}^{-1}$ of fresh fruit weight is required to make quality wine (NAOR et al., 2002) and similar result was found by Bubola et al. (2011) who determined $15 \mathrm{~cm}^{2}$. However, Kliewer and Antcliff (1970) and Smart (1985) found lower values, ranging from 7 to 10 $\mathrm{cm}^{2} \cdot \mathrm{g}^{-1}$. In addition, there was a considerable ${ }^{\circ}$ Brix increase when this ratio varied from 6 to $12 \mathrm{~cm}^{2}$ (PASTORE et al., 2011).

It is possible to assert that most rootstocks used in this trial are suitable for the Serra Gaúcha conditions because they have tolerance going from dry to wet soils and from low to high vigor of grapevines. Moreover, except for Dogridge, most rootstocks have high tolerance to phylloxera (HARDIE; CIRAMI, 1988; CHRISTENSEN et al., 2003), an important pest in this region and the main reason why grapevines should be grafted. Today, $1103 \mathrm{P}$ is one of the most used rootstocks due to its tolerance to fusarium. Nevertheless, other insects, fungi and even nematodes may be present in soils and there is still no response to them. Furthermore, compatibility and affinity between rootstock and scion should be considered.

So, the choice of the right rootstock by growers mainly depends on aspects related to soil physicochemical properties, presence of fungi, insects and nematodes, climate conditions, grape variety - and even clone - and production purposes. 
TABLE 1 - Effect of rootstock on the budbreak, number of clusters and yield of Cabernet Sauvignon grapevine cultivated in the viticultural region of Serra Gaúcha, RS, Brazil, over two years.

\begin{tabular}{|c|c|c|c|c|c|c|c|}
\hline & \multirow{2}{*}{$\begin{array}{c}\text { Budbreak } \\
(\%)\end{array}$} & \multicolumn{3}{|c|}{$\mathrm{N}^{\circ}$ of clusters } & \multicolumn{3}{|c|}{ Yield } \\
\hline & & Bud & Burst bud & Vine & Bud (g) & Burst bud (g) & Vine (kg) \\
\hline \multicolumn{8}{|l|}{ Rooststock } \\
\hline Rup. du Lot & $76.8^{\mathrm{a}} \mathrm{ab}$ & $1.42 \mathrm{ab}$ & $1.89 \mathrm{ab}$ & $66.0 \mathrm{abcd}$ & $250.2 \mathrm{bc}$ & $331.7 \mathrm{bc}$ & $11.64 \mathrm{bcd}$ \\
\hline 101-14 Mgt. & $73.2 \mathrm{abc}$ & $1.42 \mathrm{ab}$ & $1.97 \mathrm{ab}$ & $54.7 \mathrm{~cd}$ & $252.7 \mathrm{bc}$ & $348.9 \mathrm{abc}$ & $10.24 \mathrm{~d}$ \\
\hline $3309 \mathrm{C}$ & $71.5 \mathrm{bc}$ & $1.59 \mathrm{ab}$ & $2.30 \mathrm{ab}$ & $65.8 \mathrm{abcd}$ & $284.3 \mathrm{abc}$ & $406.5 \mathrm{abc}$ & $11.67 \mathrm{bcd}$ \\
\hline 420A Mgt. & $79.6 \mathrm{ab}$ & $1.53 \mathrm{ab}$ & $1.94 \mathrm{ab}$ & $65.3 \mathrm{abcd}$ & $323.5 \mathrm{abc}$ & $409.1 \mathrm{abc}$ & $14.03 \mathrm{abcd}$ \\
\hline $5 B B \mathrm{~K}$ & $74.3 \mathrm{abc}$ & $1.68 \mathrm{ab}$ & $2.37 \mathrm{a}$ & $67.7 \mathrm{abcd}$ & $333.3 \mathrm{abc}$ & $469.0 \mathrm{abc}$ & $13.39 \mathrm{bcd}$ \\
\hline $161-49 \mathrm{C}$ & $82.3 \mathrm{ab}$ & $1.42 \mathrm{ab}$ & $1.77 \mathrm{ab}$ & $55.8 \mathrm{bcd}$ & $286.5 \mathrm{abc}$ & $355.1 \mathrm{abc}$ & $11.29 \mathrm{~cd}$ \\
\hline $\mathrm{SO} 4$ & $76.0 \mathrm{ab}$ & $1.86 \mathrm{a}$ & $2.45 \mathrm{a}$ & $73.7 \mathrm{ab}$ & $396.5 \mathrm{a}$ & $522.7 \mathrm{a}$ & $15.84 \mathrm{ab}$ \\
\hline Solferino & $74.6 \mathrm{ab}$ & $1.63 \mathrm{ab}$ & $2.33 \mathrm{ab}$ & $80.8 \mathrm{a}$ & $355.4 \mathrm{ab}$ & $501.7 \mathrm{ab}$ & $17.75 \mathrm{a}$ \\
\hline $1103 \mathrm{P}$ & $76.8 \mathrm{ab}$ & $1.71 \mathrm{a}$ & $2.33 \mathrm{ab}$ & $70.5 \mathrm{abcd}$ & $307.3 \mathrm{abc}$ & $421.3 \mathrm{abc}$ & $12.70 \mathrm{bcd}$ \\
\hline $99 \mathrm{R}$ & $77.5 \mathrm{ab}$ & $1.65 \mathrm{ab}$ & $2.21 \mathrm{ab}$ & $73.2 \mathrm{ab}$ & $314.1 \mathrm{abc}$ & $415.6 \mathrm{abc}$ & $13.94 \mathrm{abcd}$ \\
\hline $110 \mathrm{R}$ & $82.8 \mathrm{a}$ & $1.64 \mathrm{ab}$ & $2.04 \mathrm{ab}$ & $70.5 \mathrm{abcd}$ & $323.3 \mathrm{abc}$ & $401.3 \mathrm{abc}$ & 13.89 abcd \\
\hline Gravesac & $79.7 \mathrm{ab}$ & $1.72 \mathrm{a}$ & $2.23 \mathrm{ab}$ & $71.0 \mathrm{abc}$ & $342.5 \mathrm{ab}$ & $441.0 \mathrm{abc}$ & 14.18 abcd \\
\hline Fercal & $76.3 \mathrm{ab}$ & $1.65 \mathrm{ab}$ & $2.23 \mathrm{ab}$ & $72.2 \mathrm{abc}$ & $339.6 \mathrm{abc}$ & $456.8 \mathrm{abc}$ & $14.91 \mathrm{abc}$ \\
\hline Dogridge & $63.1 \mathrm{c}$ & $1.23 \mathrm{ab}$ & $2.17 \mathrm{ab}$ & $64.5 \mathrm{abcd}$ & $270.0 \mathrm{abc}$ & $477.7 \mathrm{ab}$ & $14.19 \mathrm{abcd}$ \\
\hline Isabel & $72.8 \mathrm{abc}$ & $1.05 \mathrm{~b}$ & $1.51 \mathrm{~b}$ & $52.3 \mathrm{~d}$ & $208.4 \mathrm{c}$ & $296.6 \mathrm{c}$ & $10.38 \mathrm{~d}$ \\
\hline \multicolumn{8}{|l|}{ Significance $^{\mathrm{b}}$} \\
\hline $\mathrm{R}$ & $0.00002 * *$ & $0.00396 * *$ & $0.01155^{*}$ & $0.00002 * *$ & $0.00065 * *$ & $0.00079 * *$ & $<0.00001 * *$ \\
\hline $\mathrm{Y}$ & $<0.00001 * *$ & $<0.00001 * *$ & $<0.00001 * *$ & $<0.00001 * *$ & $<0.000001 * *$ & $<0.00001 * *$ & $<0.00001 * *$ \\
\hline $\mathrm{R} \times \mathrm{Y}$ & $0.00764 *$ & $0.54026^{\text {ns }}$ & $0.32046^{\mathrm{ns}}$ & $0.16535^{\mathrm{ns}}$ & $0.28780^{\mathrm{ns}}$ & $0.02304 *$ & $0.17839^{\text {ns }}$ \\
\hline
\end{tabular}

a Rootstock means within columns followed by different lower case letters differ significantly at $\mathrm{p}<0.05$ by Tukey's multiple range test; ${ }^{\mathrm{b}}$ Significance of rootstock (R), year (Y) and R x Y interactions.

TABLE 2- Effect of rootstock on the cluster weight, pruning weight and leaf area of Cabernet Sauvignon grapevine cultivated in the viticultural region of Serra Gaúcha, RS, Brazil, over two years.

\begin{tabular}{|c|c|c|c|c|c|c|}
\hline & $\begin{array}{c}\text { Cluster } \\
\text { weight }(\mathrm{g})\end{array}$ & $\begin{array}{c}\text { Pruning weight/ } \\
\text { Vine }(\mathrm{kg})\end{array}$ & $\begin{array}{r}\text { Yield } / \text { Pruning } \\
\text { weight }(\mathrm{kg} / \mathrm{kg})\end{array}$ & $\begin{array}{l}\text { Leaf area/ } \\
\text { Vine }\left(\mathrm{m}^{2}\right)\end{array}$ & $\begin{array}{c}\text { Leaf area } \\
\text { index }\end{array}$ & $\begin{array}{c}\text { Leaf area/ } \\
\text { Fresh fruit weight }\left(\mathrm{cm}^{2} / \mathrm{g}\right)\end{array}$ \\
\hline \multicolumn{7}{|l|}{ Rootstock } \\
\hline Rup. du Lot & $179.5^{\mathrm{a}} \mathrm{b}$ & $3.01 \mathrm{abc}$ & $4.49 \mathrm{bcd}$ & $13.2 \mathrm{a}$ & $2.95 \mathrm{a}$ & $12.58 \mathrm{a}$ \\
\hline 101-14 Mgt. & $192.7 \mathrm{ab}$ & 2.52 bcde & $4.65 \mathrm{bcd}$ & $9.2 \mathrm{ab}$ & $2.06 \mathrm{~cd}$ & $9.03 \mathrm{ab}$ \\
\hline $3309 \mathrm{C}$ & $178.0 \mathrm{~b}$ & 2.57 bcde & $4.76 \mathrm{bcd}$ & $11.0 \mathrm{ab}$ & $2.46 \mathrm{abcd}$ & $9.78 \mathrm{ab}$ \\
\hline 420A Mgt. & $217.7 \mathrm{a}$ & 2.10 cde & $7.11 \mathrm{abc}$ & $11.5 \mathrm{ab}$ & $2.58 \mathrm{abcd}$ & $8.38 \mathrm{ab}$ \\
\hline $5 B B \mathrm{~K}$ & $198.2 \mathrm{ab}$ & $2.91 \mathrm{abcd}$ & $4.91 \mathrm{bcd}$ & $10.8 \mathrm{ab}$ & $2.41 \mathrm{abcd}$ & $8.57 \mathrm{ab}$ \\
\hline $161-49 \mathrm{C}$ & $202.8 \mathrm{ab}$ & $1.54 \mathrm{de}$ & $7.63 \mathrm{ab}$ & $8.8 \mathrm{ab}$ & $1.95 \mathrm{~d}$ & $7.58 \mathrm{~b}$ \\
\hline $\mathrm{SO} 4$ & $218.7 \mathrm{a}$ & $3.63 \mathrm{ab}$ & $4.72 \mathrm{bcd}$ & $12.4 \mathrm{ab}$ & $2.76 \mathrm{a}$ & $8.13 \mathrm{ab}$ \\
\hline Solferino & $223.3 \mathrm{a}$ & $3.62 \mathrm{ab}$ & $5.35 \mathrm{abcd}$ & $12.1 \mathrm{ab}$ & $2.71 \mathrm{abc}$ & $7.03 \mathrm{~b}$ \\
\hline $1103 \mathrm{P}$ & $179.5 \mathrm{~b}$ & $2.89 \mathrm{abcd}$ & $5.36 \mathrm{abcd}$ & $12.4 \mathrm{ab}$ & $2.75 \mathrm{ab}$ & $10.35 \mathrm{ab}$ \\
\hline $99 \mathrm{R}$ & $195.0 \mathrm{ab}$ & 2.44 bcde & $5.98 \mathrm{abcd}$ & $9.3 \mathrm{ab}$ & $2.08 \mathrm{bcd}$ & $6.78 \mathrm{~b}$ \\
\hline $110 \mathrm{R}$ & $200.0 \mathrm{ab}$ & 2.17 cde & $6.94 \mathrm{abc}$ & $8.6 \mathrm{~b}$ & $1.93 \mathrm{~d}$ & $6.72 \mathrm{~b}$ \\
\hline Gravesac & $202.5 \mathrm{ab}$ & $4.08 \mathrm{a}$ & $3.77 \mathrm{~cd}$ & $9.2 \mathrm{ab}$ & $2.06 \mathrm{~cd}$ & $6.58 \mathrm{~b}$ \\
\hline Fercal & $211.2 \mathrm{ab}$ & $3.69 \mathrm{ab}$ & $4.40 \mathrm{bcd}$ & $12.1 \mathrm{ab}$ & $2.66 \mathrm{abc}$ & $8.28 \mathrm{ab}$ \\
\hline Dogridge & $218.2 \mathrm{a}$ & $4.28 \mathrm{a}$ & $3.43 \mathrm{~d}$ & $12.9 \mathrm{ab}$ & $2.88 \mathrm{a}$ & $9.42 \mathrm{ab}$ \\
\hline Isabel & $201.7 \mathrm{ab}$ & $1.44 \mathrm{e}$ & $8.37 \mathrm{a}$ & $10.8 \mathrm{ab}$ & $2.38 \mathrm{abcd}$ & $10.77 \mathrm{ab}$ \\
\hline \multicolumn{7}{|l|}{ Significance $^{b}$} \\
\hline $\mathrm{R}$ & $0.01809 *$ & $<0.00001 * *$ & $0.00002 * *$ & $0.00168 * *$ & $0.00200 * *$ & $0.00060 * *$ \\
\hline $\mathrm{Y}$ & $<0.00001 * *$ & $<0.00001 * *$ & $<0.00001 * *$ & $0.00017 * *$ & $0.00022 * *$ & $<0.00001 * *$ \\
\hline $\mathrm{R} \times \mathrm{Y}$ & $0.40346^{\mathrm{ns}}$ & $0.84338^{\mathrm{ns}}$ & $0.55764^{\mathrm{ns}}$ & $0.04513 *$ & $0.04774 *$ & $0.21232^{\mathrm{ns}}$ \\
\hline
\end{tabular}

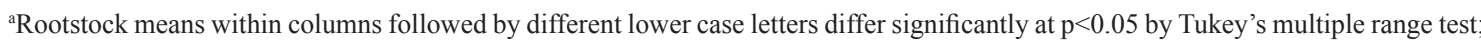
${ }^{\mathrm{b}}$ Significance of rootstock (R), year (Y) and R x Y interactions. 


\section{CONCLUSIONS}

All scion/rootstock combinations have high yields, which is due to the number of clusters/vine and the relatively high cluster weight. In addition, they transmit vigor to grapevines, which is due to soil fertility and the climate conditions found in Serra Gaúcha.

The yield/pruning weight ratio, which gives an idea of the reproductive and vegetative performance of grapevines, has adequate values for vineyards conducted in this region, and the leaf area/ fresh fruit ratio has values considered adequate to mature and produce quality grapes.

\section{ACKNOWLEDGEMENTS}

Authors gratefully thank Embrapa Uva e Vinho colleagues who worked during seven years in this experiment; Dr. Adeliano Cargnin and Dr. Ricardo Valgas, from Embrapa Uva e Vinho and Embrapa Clima Temperado, respectively, for their collaboration; and to Inra-Centre BordeauxAquitaine for its kindness to provide some vegetative material for this research.

\section{REFERENCES}

BOTTON, M.; DALLA COLLETA, V. Avaliação da resistência de cultivares de Vitis rotundifolia à pérolada-terra (Hemiptera: Margarodidae) na região sul do Brasil. Acta Scientiarum. Agronomy, Maringá, v.32, p.213-216, 2010.

BRAVDO, B.; HEPNER, Y.; LOINGER, C.; COHEN, S.; TABACMAN, H. Effect of crop level and crop load on growth, yield, must and wine composition, and quality of Cabernet Sauvignon. American Journal of Enology and Viticulture, Davis, v.36, p.125-131, 1985.

BROWN, D.S.; JASPERS, M.V.; RIDGWAY, H.J.; BARCLAY, C.J.; JONES, E.E. Susceptibility of four grapevine rootstocks to Cylindrocladiella parva. New Zealand Plant Protection, Wellington, v.66, p.249-253, 2013.

BUBOLA, M.; PERSURIC, D.; GANIC, K.K. Impact of cluster thinning on productive characteristics and wine phenolic composition of cv. Merlot. Journal of Food, Agriculture \& Environment, Helsinki, v.9, p.36-39, 2011.
CHRISTENSEN, L.P.; DOKOOZLIAN, N.; WALKER, M.A.; WOLPERT, J.A. Wine grape in California. Oakland: University of California Agricultural and Natural Resources, 2003. (Publication, 3419).

COOKSON, S.J.; HEVIN, C.; DONNART, D.; OLLAT, N. Grapevine rootstock effects on scion biomass are not associated with large modifications on primary shoot growth under non limiting conditions in the first year of growth. Functional Plant Biology, Chichester, v.39, p.650-660, 2012.

DE HERRALDE, F.; ALSINA, M.M.; ARANDA, X.; SAVÉ, R.; BIEL, C. Effects of rootstock and irrigation regime on hydraulic architecture of Vitis vinifera L. cv. Tempranillo. Journal International des Sciences de la Vigne et du Vin, Bordeaux, v.40, p.133-139, 2006.

FERRIS, H.; ZHENG, L.; WALKER, M.A. Resistance of grape rootstocks to plant-parasitic nematodes. Journal of Nematology, College Park, v.44, p.377-386, 2012.

GRIGOLETTI JÚNIOR, A. Fusariose da videira: resistência de cultivares, sintomas e controle. Bento Gonçalves: Embrapa-Centro Nacional de Pesquisa de Uva e Vinho, 1993. 19 p. (Circular Técnica, 18).

HARDIE, W.J.; CIRAMI, R.M. Grapevine rootstocks. In: COOMBE, B.G.; DRY, P.R. Viticulture. Resources. Adelaide: Winetitle, 1988. v.1, p.154-176.

JONES, T.H.; CULLINS, B.R.; CLINGELEFFER, P.R.; RUHL, E.H. Effects of novel and traditional rootstocks on vigour and yield components of Shiraz grapevines. Australian Journal of Grape and Wine Research, Oxford, v.15, p.284-292, 2009.

KELLER, M.; MILLS, L.J.; HARBERTSON, F. Rootstock effects on deficit-irrigated winegrapes in a dry climate: vigor, yield formation, and fruit ripening. American Journal of Enology and Viticulture, Davis, v.63, p.29-39, 2012.

KLIEWER, M.W.; WEAVER, R.J. Effect of crop level and leaf area on growth, composition, and coloration of 'Tokay' grapes. American Journal of Enology and Viticulture, Davis, v.22, p.172-177, 1971. 
KLIEWER, W.M.; ANTCLIFF, A.J. Influence of defoliation, leaf darkening, and cluster shading on the growth and composition of Sultana grapes. American Journal of Enology and Viticulture, Davis, v.21, n.1, p.26-36, 1970.

KODUR, S.; TISDALL, J.M.; TANG, C.; WALKER, R.R. Uptake, transport, accumulation and translocation of potassium in grapevine rootstocks (Vitis). Vitis, Siebeldingen, v.50, p.145-149, 2011.

MIELE, A.; MANDELLI, F. Manejo do dossel vegetativo e seu efeito nos componentes de produção da videira Merlot. Revista Brasileira de Fruticultura, Jaboticabal, v.34, p.964-973, 2012.

MIELE, A.; RIZZON, L.A. Intensidades da poda seca e do desbaste de cacho na composição da uva Cabernet Sauvignon. Revista Brasileira de Fruticultura, Jaboticabal, v.35, p.1081-1092, 2013.

MIELE, A.; RIZZON, L.A.; GIOVANNINI, E. Effect of rootstock on nutrient content of 'Cabernet Sauvignon' grapevine tissues. Revista Brasileira de Fruticultura, Jaboticabal, v.31, p.1141-1149, 2009.

MIELE, A.; RIZZON, L.A.; SILVA, J.G.C. da. Determinação da área foliar da videira cv. Cabernet Sauvignon utilizando medidas lineares do limbo. In: CONGRESSO BRASILEIRO DE FRUTICULTURA, 10., 1989, Fortaleza. Anais... Fortaleza: Sociedade Brasileira de Fruticultura, 1989. p.467-474.

NAOR, A.; GAL, Y.; BRAVDO, B. Shoot and cluster thinning influence vegetative growth, fruit yield, and wine quality of 'Sauvignon blanc' grapevines. Journal of the American Society for Horticultural Science, Alexandria, v.127, p.628-634, 2002.

ORLANDO, T.D.S.; PEDRO JUNIOR, M.; SANTOS, A.O.; HERNANDES, J.L. Yieldrelated performance of cv. Cabernet Sauvignon and Petite Syrah on different rootstocks. Ciência e Agrotecnologia, Lavras, v.32, p.749-755, 2008.
PASTORE, C.; ZENONI, S.; TORNIELLI, G.B.; ALLEGRO, G.; DAL SANTO, S.; VALENTINI, G.; INTRIERI, C.; PEZZOTTI, M.; FILIPPETTI, I. Increasing the source/sink ratio in Vitis vinifera (cv. Sangiovese) induces extensive transcriptome reprogramming and modifies berry ripening. BMC Genomics, London, v.12, n.631, 2011.

POUGET, R. Histoire de la lutte contre le phylloxera de la vigne en France. Paris: Inra; OIV, 1990.

ROSA, C.; JIMENEZ, J.F.; MARGARIA, P.; ROWHANI, A. Symptomatology and effects of viruses associated with rugose wood complex on the growth of four different rootstocks. American Journal of Enology and Viticulture, Davis, v.62, p.207-213, 2011.

SERRA, I.; STREVER, A.; MYBURGH, P.A.; DELOIRE, A. Review: the interaction between rootstocks and cultivars (Vitis vinifera L.) to enhance drought tolerance in grapevine. Australian Journal of Grape and Wine Research, Glen Usmond, v.20, p.1-14, 2014

SMART, R.E. Principles of grapevine canopy microclimate manipulation with implications for yield and quality. A review. American Journal of Enology and Viticulture, Davis, v.36, p.230-239, 1985.

SOMKUWAR, R.G.; JOGAIAH, S.; SAWANT, S.D.; TAWARE, P.B.; BONDAGE, D.D.; ITROUTWAR, P. Rootstocks influence the growth, biochemical contents and disease incidence in Thompson Seedless grapevines. British Journal of Applied Science \& Technology, London, v.4, p.1030-1041, 2014.

SÔNEGO, O.R. Avaliação de porta-enxertos de videira frente à fusariose, em condições de campo. Bento Gonçalves: Embrapa-Centro Nacional de Pesquisa de Uva e Vinho, 1998. (Comunicado Técnico, 28).

SOUZA, C.R. de; MOTA, R.V. da; FRANÇA, D.V.C.; PIMENTEL, R.M. de A.; REGINA, M. de A. Cabernet Sauvignon grapevine grafted onto rootstocks during the autumn-winter season in southeastern Brazilian. Scientia Agricola, Piracicaba, v.72, p.138-146, 2015. 
TERRA, M.M.; PIRES, E.J.P.; POMMER, C.V.; BOTELHO, R.V. Produtividade da uva de mesa Niagara Rosada sobre diferentes porta-enxertos, em Monte Alegre do Sul-SP. Revista Brasileira de Fruticultura, Jaboticabal, v.25, n.3, p.549-551, 2003.

VIRGONA, J.M.; SMITH, J.P.; HOLZAPFEL, B.P. Scions influence apparent transpiration efficiency of Vitis vinifera (cv. Shiraz) rather than rootstocks. Australian Journal of Grape and Wine Research, Glen Osmond, v.9, p.183-185, 2003.
WALKER，R.R.; BLACKMORE，D.H.; CLINGELEFFER, P.R.; TARR, C.R. Rootstocks effects on salt tolerance of irrigated-grown grapevines (Vitis vinifera L. cv. Sultana). 3. Fresh fruit composition and dried grape quality. Australian Journal of Grape and Wine Research, Glen Osmond, v.13, p.130-141, 2007.

WALLIS, C.M.; WALLINGFORD, A.K.; CHEN, J.C. Grapevine rootstock effects on scion sap levels, resistance to Xylella fastidiosa infection, and progression of Pierce's disease. Frontiers in Plant Science, New Haven, v.4, p.816-826, 2013. 